\title{
SIKAP, PENGAMBILAN KEPUTUSAN DAN KEPUASAN KONSUMEN TERHADAP AGROINDUSTRI PIE PISANG DI KOTA BANDAR LAMPUNG
}

\author{
(Attitudes, decision-making and customer satisfaction on banana pie agroindusty \\ in Bandar Lampung City)
}

Wayan Elpa Andela, Teguh Endaryanto, Rabiatul Adawiyah

Jurusan Agribisnis, Fakultas Pertanian, Universitas Lampung, J1. Prof. Dr. Soemantri Brodjonegoro No. 1 Bandar Lampung 35145, e-mail: teguh.endaryanto@fp.unila.ac.id

\begin{abstract}
This study aims to determine consumer characteristics, attitudes, decision-making processes, and customer satisfaction towards banana pie at YA and JB. The research samples were 66 people selected by accidental sampling. The first and third objectives were analyzed descriptively, the second objective was analyzed using the Multiatribut Fishbein model, and the fourth objective was analyzed using Costumer Statisfaction Index (CSI) and Importance Performance Analysis (IPA). The results showed that the characteristics of consumers of banana pie were dominated by female 18-30 years old who earned Rp1,500,000.00 Rp2,500,000.00/month. The frequency of buying banana pie on average was once a week. The consumer decision making process on purchasing banana pie, at YA and JB was the same, namely the introduction of needs, information seeking, evaluation of alternatives, purchasing decisions, and post-purchase evaluation. Consumers of banana pie at JB gave an attitude value of 178.40, those at YA gave an attitude value of 180. The satisfaction level of banana pie consumers at JB was $77.86 \%$ and $78.76 \%$ at $Y A$, both were included in the satisfied category. The attribute of banana pie that was needed to be improved at JB was the expire date, whereas there was no attribute needed to be improved at YA.
\end{abstract}

Key words : Attitude, CSI, IPA, purchasing decisions

\section{PENDAHULUAN}

Pisang merupakan salah satu buah yang digemari oleh sebagian besar penduduk, karena rasanya yang enak, kandungan gizinya yang tinggi, dan mudah didapat (Satuhu 2000). Provinsi Lampung merupakan salah satu provinsi dengan produksi buah pisang tertinggi di mana memiliki luas tanam sebesar 1.937.348 ha pada tahun 2015 (Direktorat Jenderal Hortikultura 2015).

Pisang merupakan salah satu jenis buah-buahan yang memiliki nilai ekonomis yang tinggi dan mempunyai peluang usaha yang menjanjikan. Melimpahnya produksi pisang di Provinsi Lampung membuat banyak usaha makanan yang memanfaatkan pisang menjadi berbagai produk olahan pisang. Olahan pisang yang banyak dijumpai saat ini yaitu keripik pisang, sale pisang, tepung pisang, bolu pisang, dan pie pisang. Pie pisang merupakan produk olahan yang berbahan baku pisang. Pie pisang kini banyak disukai oleh masyarakat dan dijadikan cemilan, karena rasanya yang khas dan enak. Pie pisang juga dapat dijadikan oleh-oleh khas Provinsi Lampung. Provinsi Lampung, khususnya Kota Bandar
Lampung merupakan daerah yang memiliki industri pengolahan pastry yang cukup berkembang. Saat ini banyak agroindustri di Bandar Lampung yang sudah mengembangkan produk pie pisang yaitu Agroindustri JB dan YA. Ke dua toko kue ini sudah tidak asing lagi di kalangan masyarakat, khususnya Kota Bandar Lampung. Persaingan bisnis antara ke dua toko kue tersebut dapat dilihat dari tempatnya yang saling berdekatan yaitu berada di Jalan Zainal Abidin Pagar Alam dan dengan menu makanan yang relatif sama.

Konsumen memiliki sikap dan pertimbanganpertimbangan tertentu untuk mengambil keputusan, yaitu kepercayaan konsumen terhadap produk tersebut, seperti atribut yang terkandung dalam produk tersebut. Terdapat beberapa atribut produk pada pie pisang yaitu variasi rasa, harga, ukuran, tanggal kadaluarsa, kemasan, tekstur dan atribut tempat yaitu lokasi, area parkir, kebersihan tempat dan kenyamanan tempat. Menurut Mowen dan Minor (2002), kepuasan konsumen adalah keseluruhan sikap yang ditunjukkan oleh seorang konsumen terhadap suatu produk baik barang dan jasa setelah mereka membeli dan menggunakan 
barang tersebut. Berbagai macam produk pie pisang yang dijual di pasaran menyebabkan persaingan antar produsen pie pisang, sehingga para pemasar pie pisang perlu lebih cermat dalam memenangkan persaingan yang dihadapinya dalam memperebutkan konsumen. Agroindustri juga dituntut untuk menciptakan dan mempertahankan pelanggan berdasarkan sikap yang mereka lakukan berdasarkan atribut pie pisang. Mereka akan melakukan proses pengambilan keputusan pembelian yang berulang pada produk tersebut, karena konsumen merasa puas terhadap produk yang telah dikonsumsinya. Berdasarkan uraian latar belakang, maka penelitian ini bertujuan untuk menganalisis karakteristik konsumen, proses pengambilan keputusan konsumen, sikap konsumen, dan kepuasan konsumen pie pisang di JB dan YA.

\section{METODE PENELITIAN}

Penelitian ini dilakukan di YA dan JB dengan pertimbangan bahwa keduanya merupakan toko kue yang menjual dan memproduksi pie pisang dan sudah memiliki beberapa cabang di Kota Bandar Lampung. Jumlah responden pada penelitian ini adalah 66 orang.

Pengambilan sampel dilakukan dengan metode non-probability yaitu Accidental Sampling. Accidental Sampling merupakan teknik pengambilan sampel yang diambil dari anggota populasi yang dapat ditemui di lokasi pengambilan data dan dengan mudah dapat memberikan informasi yang diinginkan serta masuk ke dalam kriteria pengambilan sampel (Sugiyono 2010). Pada penarikan sampel, peneliti mempunyai kebebasan memilih siapapun konsumen yang dijadikan responden. Penentuan jumlah sampel pada penelitian ini, merujuk pada rumus Isaac dan Michael (1981) sebagai berikut.

$$
\mathrm{n}=\frac{\mathrm{N} \mathrm{Z} \mathrm{Z}^{2}}{\mathrm{~N} \mathrm{~d}^{2}+\mathrm{Z}^{2} \mathrm{~S}^{2}}
$$

\section{Keterangan:}

$$
\begin{array}{ll}
\mathrm{n} & =\text { Jumlah sampel } \\
\mathrm{N} & =\text { Jumlah populasi anggota } \\
\mathrm{Z} & =\text { Derajat kepercayaan }(95 \%=1,96) \\
S^{2} & =\text { Variasi sampel }(5 \%=0,05) \\
\mathrm{d} & =\text { Derajat penyimpangan }(5 \%=0,05)
\end{array}
$$

Penentuan sampel pada penelitian ini merujuk pada teori Isac dan Micheal (1981) dimana penentuan sampel ditentukan berdasarkan jumlah populasi konsumen yang membeli pie pisang di YA dan di
JB. Jumlah populasi konsumen yang membeli pie pisang di YA sebesar 60 konsumen dan 55 konsumen di JB. Jumlah populasi ini diperoleh berdasarkan hasil turun lapang yang telah dilakukan selama dua minggu. Total jumlah responden yang diwawancarai sebanyak 66 sampel, dimana 34 responden di YA dan 32 Responden di JB sehingga dapat ditentukan jumlah sampel sebagai berikut:

Sampel penelitian di YA:

$\mathrm{n}=\frac{(60)(1,96)^{2}(0,05)}{(60)\left(0,05^{2}\right)+(1,96)^{2} 0,05}=34$ Responden

Sampel penelitian di JB:

$\mathrm{n}=\frac{(55)(1,96)^{2}(0,05)}{(55)\left(0,05^{2}\right)+(1,96)^{2} 0,05}=32$ Responden

Sebelum melakukan analisis sikap konsumen terhadap pie pisang, terlebih dahulu dilakukan uji validitas dan reliabilitas untuk menguji atribut pie pisang pada kuesioner. Uji validitas dan reliabilitas digunakan untuk menunjukkan sejauh mana suatu alat ukur mampu mengukur apa yang ingin diukur dan dapat diandalkan. Pengujian dilakukan dengan tujuan untuk mengetahui apakah pertanyaan dalam kuesioner sudah valid dan reliable, sehingga apabila pertanyaan sudah valid dan reliable, maka dapat digunakan untuk mengukur instrumen yang ada. Pengujian dilakukan pada 30 responden pada masing-masing agroindustri pie pisang.

Ghozali (2009) menyatakan bahwa uji validitas digunakan untuk mengukur sah atau valid tidaknya suatu kuesioner. Nilai validitas dapat dikatakan baik, jika nilai corrected item dari total correlation bernilai di atas 0,20. Apabila nilai correlation sudah di atas 0,20 maka butir-butir tersebut dikatakan valid. Menurut Ghozali (2005), suatu instrumen dikatakan reliabel, jika nilai cronbach alpha lebih dari 0,60. Uji validitas dan reliabilitas dapat dilakukan dengan menggunakan Statistical Package for the Social Sciences (SPSS 17). Hasil uji validitas dan reliabilitas tingkat kepentingan dan tingkat kepercayaan pie pisang di YA dan JB dapat dilihat pada Tabel 1 dan 2 .

Nilai Corrected item-total correlation dari masingmasing atribut di atas 0,20 yang menunjukkan bahwa pertanyaan yang diajukan di dalam kuesioner adalah valid. Pada uji reliabilitas semua pertanyaan yang diajukan di dalam kuesioner juga dinyatakan reliabel, karena nilainya di atas 0,60. 
Tabel 1. Hasil uji validitas dan reliabilitas tingkat kepentingan dan tingkat kepercayaan pie pisang di YA

\begin{tabular}{lcc}
\hline Variabel indikator & $\begin{array}{c}\text { Tingkat } \\
\text { kepentingan } \\
\text { pie pisang }\end{array}$ & $\begin{array}{c}\text { Tingkat } \\
\text { kepercayaan } \\
\text { pie pisang YA }\end{array}$ \\
\cline { 2 - 3 } Rasa & \multicolumn{2}{c}{$\begin{array}{c}\text { Corrected Item- Total } \\
\text { Correlation }\end{array}$} \\
Harga & 0,487 & 0,236 \\
Ukuran & 0,328 & 0,380 \\
Variasi produk & 0,254 & 0,234 \\
Higenitas & 0,467 & 0,308 \\
Tanggal kadaluarsa & 0,415 & 0,270 \\
Kemasan & 0,465 & 0,260 \\
Tekstur & 0,396 & 0,359 \\
Lokasi & 0,387 & 0,329 \\
Area parkir & 0,452 & 0,586 \\
Kenyamanan & 0,358 & 0,552 \\
Kebersihan & 0,222 & 0,349 \\
Hasil uji reliabilitas & 0,503 & 0,547 \\
Cronbach's Alpha & tingkat kepentingan & pie pisang \\
0,738 & & \\
\hline Cronbach's Alpha tingkat kepentingan pie pisang YA \\
0,734
\end{tabular}

Tabel 2. Hasil uji validitas dan reliabilitas tingkat kepentingan dan kepercayaan pie pisang di JB

\begin{tabular}{lcc}
\hline \multicolumn{1}{c}{$\begin{array}{l}\text { Variabel } \\
\text { indikator }\end{array}$} & $\begin{array}{c}\text { Tingkat } \\
\text { kepentingan } \\
\text { pie pisang }\end{array}$ & $\begin{array}{c}\text { Tingkat } \\
\text { kepercayaan } \\
\text { pie pisang JB }\end{array}$ \\
\cline { 2 - 3 } Rasa & \multicolumn{2}{c}{$\begin{array}{c}\text { Corrected Item- Total } \\
\text { Correlation }\end{array}$} \\
Harga & 0,487 & 0,318 \\
Ukuran & 0,328 & 0,273 \\
Variasi produk & 0,254 & 0,204 \\
Higenitas & 0,467 & 0,279 \\
Tanggal kadaluarsa & 0,415 & 0,205 \\
Kemasan & 0,465 & 0,524 \\
Tekstur & 0,396 & 0,368 \\
Lokasi & 0,387 & 0,245 \\
Area parkir & 0,452 & 0,465 \\
Kenyamanan & 0,358 & 0,442 \\
Kebersihan & 0,222 & 0,331 \\
Hasil uji reliabilitas & 0,503 & 0,384 \\
Cronbach's Alpha & tingkat kepentingan & pie pisang \\
0,738 & & \\
\hline Cronbach's Alpha tingkat kepentingan pie pisang JB \\
0,699
\end{tabular}

Metode deskriptif digunakan untuk menjawab tujuan pertama dan ke tiga yaitu mengetahui karakteristik dan proses pengambilan keputusan konsumen pie pisang yang ada di YA dan JB.
Proses pengambilan keputusan konsumen meliputi tahapan pengenalan kebutuhan, pencarian informasi, evaluasi alternatif, keputusan pembelian dan evaluasi pasca pembelian. Analisis Multiatribut Fishbein yaitu untuk mengetahui sikap konsumen terhadap keputusan membeli pie pisang di YA dan JB. Model Multiatribut Fishbein yang digunakan dapat dijelaskan dengan rumus berikut menurut Suryani (2012) :

$A o=\sum_{i=1}^{n}$ bi ei.

Keterangan :

$A_{0}=$ Sikap terhadap suatu objek

$b_{i}=$ Kekuatan kepercayaan terhadap atribut $\mathrm{i}$

$e_{i}=$ Evaluasi terhadap atribut $\mathrm{i}$

$\mathrm{n}=$ Jumlah atribut yang dimiliki objek

Variabel Ao merupakan sikap konsumen terhadap produk pie pisang yang diperoleh dari hasil perkalian setiap skor evaluasi (ei) dengan skor kepercayaan (bi) konsumen terhadap atribut pie pisang. Komponen (ei) adalah evaluasi kepentingan atribut-atribut yang terdapat pada produk pie pisang yang diukur dengan skor (5), (4), (3), (2), dan (1). Skor (5) sangat penting, (4) penting, (3) cukup penting (2) tidak penting, (1) sangat tidak penting. Komponen (bi) sama dengan pengukuran skor evaluasi ei yaitu (5), (4), (3), (2), dan (1).

Customer satisfaction Index dapat digunakan untuk dapat mengetahui berapa persen tingkat kepuasan konsumen terhadap suatu produk atau jasa. Terdapat empat tahapan dalam menilai keputusan melalui analisis CSI. Pertama adalah Weighted Factor (WF), ke dua Weighted Score (WS), ke tiga Weighted Total (WT), dan ke empat Satisfaction Indexs. Tingkat kepuasan konsumen secara keseluruhan dapat dilihat dari kriteria tingkat kepuasan yang berdasarkan panduan survei kepuasan pelanggan yaitu sangat tidak puas $(0,00$ $0,20)$, tidak puas $(0,21-0,40)$, cukup puas $(0,41$ $0,60)$, puas $(0,61-0,80)$, dan sangat puas $(0,81$ 1,00) (Supranto 2006).

Importance and Performance Analysis digunakan untuk menggambarkan kinerja (performance) yang dipersepsikan oleh konsumen dalam bentuk diagram kartesius yang digunakan dalam menentukan kuadran yang terdapat pada analisis Importance Performance Analysis (IPA). Kuadran pada Importance Performance Analysis yaitu kuadran I (prioritas utama), kuadran II 
(pertahankan prestasi), kuadran III (prioritas rendah) dan kuadran IV (kinerja berlebih).

\section{HASIL DAN PEMBAHASAN}

\section{Karakteristik Konsumen}

Karakteristik konsumen berdasarkan jenis kelamin menunjukkan bahwa konsumen yang berjenis kelamin perempuan sebanyak 18 orang dan lakilaki sebanyak lima orang pada Agroinsustri JB, dan konsumen berjenis kelamin perempuan sebanyak 22 orang dan delapan orang laki-laki pada Agroindustri YA yang didominasi oleh konsumen yang berusia 18-30 tahun. Usia konsumen 18-30 tahun dikategorikan dalam rentang usia produktif dan sudah dapat mengambil keputusan sendiri (Mantra 2003). Hal ini sejalan dengan penelitian Nissa (2013) yang menyatakan bahwa sebagian besar konsumen teh rosela memiliki rentang usia 19-24 yang dianggap bahwa konsumen pada rentang usia ini sudah memiliki banyak informasi mengenai produk yang akan dikonsumsi.

Konsumen yang mengonsumsi pie pisang di YA dan JB sebagian besar adalah SMA yaitu sebanyak 20 orang di YA dan 16 orang di JB dengan pendapatan sebesar Rp1.500.000,00Rp2.500.000,00. Tingkat pendidikan akan dapat mempengaruhi konsumen dalam melakukan pembelian makanan, karena konsumen yang memiliki pendidikan yang lebih tinggi akan akan mengonsumsi makanan yang lebih baik dan aman bagi tubuhnya. Pekerjaan konsumen pie pisang di YA dan JB sebagian besar adalah mahasiswa $38,24 \%$ dan $31,25 \%$. Sebagian besar konsumen pie pisang adalah mahasiswa, hal ini karena ke dua agroindustri ini memiliki lokasi yang berdekatan dengan perguruan tinggi, sehingga kebanyakan responden yang berkunjung pada ke dua agroindustri ini adalah mahasiswa. Hal ini berbeda dengan penelitian Kuswara (2013) yang menyatakan bahwa sebagian besar responden kue lapis bogor bekerja sebagai pegawai swasta, hal ini dikarenakan untuk memberi buah tangan kepada rekan kerjanya. Frekuensi rata-rata pembelian pie pisang di YA dan di JB adalah pembelian dalam satu kali dalam seminggu.

\section{Proses Pengambilan Keputusan Konsumen terhadap Pembelian Pie pisang di YA dan JB}

Terdapat lima tahapan proses pengambilan keputusan responden dalam membeli pie pisang YA dan JB, yaitu pengenalan kebutuhan, pencarian informasi, evaluasi alternatif, keputusan pembelian, dan evaluasi pasca pembelian. Pengenalan kebutuhan responden terhadap pie pisang di JB, karena adanya keinginan konsumen untuk mencoba mengkonsumsi pie pisang dan proses pengenalan kebutuhan responden terhadap pie pisang di YA adalah karena cita rasa makanan pie pisang. Hal ini sejalan dengan penelitian Kuswara (2013) yang menyatakan bahwa alasan utama konsumen membeli kue lapis bogor, karena rasa yang khas dimana kue lapis bogor merupakan salah satu oleh-oleh khas bogor yang banyak diminati oleh konsumen. Namun berbeda dengan penelitian Anggiasari, Indriani, dan Endaryanto (2016) yang menyatakan alasan utama konsumen membeli karena ingin mengetahui manfaat dari sayuran organik yang sehat bagi tubuh.

Tahap pencarian informasi, konsumen akan mencari berbagai informasi mengenai produk yang akan dibelinya dengan mempelajari merek beserta ciri-ciri dari produk tersebut. Pada tahap pencarian informasi, konsumen pie pisang di YA maupun di JB memperoleh informasi melalui teman, dimana sumber promosi yang mempengaruhi konsumen untuk membeli pie pisang adalah melalui sumber dari mulut ke mulut.

Tahap evaluasi alternatif adalah proses mengevaluasi pilihan produk dan merek, pemilihan sesuai dengan keinginan konsumen. Pada penelitian ini, terdapat beberapa pertimbangan yang dirasakan oleh konsumen sebelum membeli yaitu cita rasa makanan sebesar $53,00 \%$ di YA dan $59,00 \%$ di JB. Evaluasi alternatif dari tempat ini juga dapat dilihat apabila agroindustri ini tutup, maka konsumen lebih memilih untuk membatalkan niat dengan persentase sebesar $47,00 \%$ di YA dan $53,00 \%$ di JB. Brand image dari masing-masing agroindustri ini cukup berpengaruh dalam evaluasi alternatif konsumen untuk melakukan pembelian dengan persentase sebesar $24,00 \%$ di YA dan $47,00 \%$ di JB.

Tahap pembelian merupakan kegiatan dimana konsumen dapat menentukan pilihan terhadap merek-merek yang sudah diketahui, sehingga dapat menentukan pilihan dalam melakukan pembelian terhadap suatu produk. Proses pembelian konsumen pie pisang di YA dan JB adalah tergantung keadaan, dimana konsumen banyak yang membeli pie pisang pada saat akhir pekan dengan persentase sebesar $47,00 \%$ di YA dan $53,00 \%$ di JB. Produk lain yang sering di konsumsi selain pie pisang adalah produk kue di YA dan produk roti di JB. 
Pada tahap evaluasi pasca pembelian, konsumen akan mengevaluasi pembelian yang akan dilakukan, sehingga konsumen dapat mengetahui apakah mereka merasa (puas atau tidak puas) setelah konsumen tersebut melakukan pembelian. Pada penelitian ini, responden merasa puas terhadap produk pie pisang yang ada di YA dengan persentase responden sebesar $74,00 \%$ dan $72,00 \%$ di JB.

\section{Sikap Konsumen}

Sikap merupakan evaluasi ungkapan perasaan konsumen suka atau tidak suka terhadap pie pisang. Pada penelitian ini, sikap konsumen dianalisis dengan menggunakan model Multiatribut Fishbein. Dari total nilai tingkat kepentingan dan kepercayaan terhadap atribut-atribut pie pisang, maka dapat diketahui skor sikap (Ao) konsumen. Pada Tabel 3 dapat dilihat bahwa skor tingkat evaluasi (ei) atribut rasa pie pisang dinilai tertinggi, yaitu 4,42. Hal ini menunjukkan bahwa atribut rasa merupakan atribut yang dianggap sangat penting oleh konsumen dari atribut pie pisang lainnya. Selain rasa, atribut lain yang dianggap penting oleh konsumen adalah harga. Konsumen menyatakan bahwa harga pie pisang yang ditawarkan bervariasi dan dapat dijangkau. Perhitungan analisis sikap Multiatribut Fishbein terhadap pie pisang di YA dan JB dapat dilihat pada Tabel 3.

Tabel 3. Skor tingkat evaluasi kepentingan (ei) terhadap atribut pie pisang dan tingkat kepercayaan (bi) terhadap atribut pie pisang YA dan JB

\begin{tabular}{|c|c|c|c|c|c|}
\hline \multirow{2}{*}{ Atribut } & \multirow{2}{*}{$\begin{array}{l}\text { Pie } \\
\text { Pisang } \\
\text { (ei) }\end{array}$} & \multicolumn{2}{|c|}{ Pie Pisang YA } & \multicolumn{2}{|c|}{ Pie Pisang JB } \\
\hline & & (bi) & (ei.bi) & (bi) & (ei.bi) \\
\hline Rasa & 4,42 & 4,35 & 19,26 & 4,34 & 19,22 \\
\hline Haror & 4,30 & 4,24 & 18,22 & & \\
\hline Ukur: & 3,53 & 3,47 & 12,25 & 3,47 & 12,25 \\
\hline $\begin{array}{l}\text { Varia } \\
\text { Prodi }\end{array}$ & 3,68 & 3,97 & 14,62 & 3,63 & 13,35 \\
\hline Higer & 4,05 & 4,12 & 16,66 & 4,13 & 16,69 \\
\hline $\begin{array}{l}\text { Tanggal } \\
\text { Kadaluarsa }\end{array}$ & 3,95 & 4,00 & 15,82 & 3,69 & 14,58 \\
\hline & 3,61 & 3,79 & 13,68 & 356 & 12,85 \\
\hline Teks & 3,65 & 4,00 & 14,61 & 3,59 & 13,12 \\
\hline Lokasi & 3,71 & 3,82 & 14,19 & 3,97 & 14,73 \\
\hline & 3,52 & 3, & 12,30 & & \\
\hline & 3,67 & 3,8 & 14,0 & 3,9 & 14,55 \\
\hline Kebersihan & 3,88 & 3,97 & 14,40 & 4,06 & 15,76 \\
\hline Ao & & & 180,06 & & 178,40 \\
\hline
\end{tabular}

Hasil penelitian ini sejalan dengan penelitian Kuswara (2013) yang menyatakan bahwa atribut rasa dianggap sangat penting, karena produk lapis bogor merupakan salah satu oleh oleh khas Bogor yang banyak diminati oleh konsumen. Berbeda dengan penelitian Syarifatunisa (2011) yang menyatakan bahwa atribut jaminan halal dianggap sangat penting dalam produk roti unyil. Tingkat kepentingan atribut pie pisang secara berturut-turut adalah atribut higenitas, tanggal kadaluarsa, kebersihan, lokasi, variasi produk, kenyamanan, tekstur, kemasan, ukuran, dan area parkir.

Skor tingkat kepercayaan tertinggi (bi) Pie pisang YA dan JB sama, dimana atribut yang dinilai tertinggi adalah rasa dan harga pie pisang. Hal ini menunjukkan bahwa rasa dan harga pie pisang dipercaya dan dianggap sudah sesuai dengan keinginan konsumen. Secara berurutan tingkat kepercayaan konsumen pada atribut pie pisang YA adalah higenitas, tanggal kadaluarsa, tekstur, variasi produk, kebersihan, kenyamanan, lokasi, kemasan, area parkir, dan ukuran. Secara berurutan kepercayaan konsumen pada atribut pie pisang di JB adalah rasa, harga, higenitas, kebersihan, lokasi, kenyamanan, area parkir, tanggal kadaluarsa, variasi produk, tekstur, kemasan, dan ukuran. Hasil perkalian skor evaluasi atribut (ei) dengan tingkat kepercayaan atribut (bi) pie pisang di YA diperoleh skor sikap (Ao) keseluruhan sebesar 180, sedangkan di JB diperoleh skor sikap sebesar 178,40. Atribut rasa baik pie pisang di YA maupun JB berkontribusi tertinggi, yaitu 19,26 dan 19,22. Hal ini sejalan dengan dengan penelitian Epriani, Indriani, dan Endaryanto (2017) yang menyatakan bahwa atribut rasa merupakan skor tertinggi dalam membeli kopi bubuk bila dibandingkan dengan atribut lainnya.

Kontribusi atribut ukuran pie pisang di YA maupun di JB sama yaitu sebesar 12,25. Hal ini menunjukkan bahwa tingkat kepentingan dan kinerja yang dirasakan oleh konsumen terhadap atribut ukuran adalah sama. Terdapat beberapa macam ukuran yang ada di YA yaitu ukuran besar, sedang dan kecil, sedangkan pada Agroindustri JB hanya terdapat satu ukuran yaitu ukuran besar, namun hal ini tidak mempengaruhi kepercayaan konsumen, sehingga tetap dapat memperoleh skor sikap yang sama. Nilai sikap atribut tanggal kadaluarsa yaitu 15,82 di YA dan 14,58 di JB. Atribut tanggal kadaluarsa pada pie pisang YA lebih tinggi bila dibandingkan dengan pie pisang JB. Hal ini dikarenakan pada kemasan pie pisang di YA terdapat tanggal kadaluarsa, sedangkan pada 
JIIA, VOLUME 8 No.2, MEI 2020

Tabel 4. Perhitungan Customer Satisfaction Index (CSI) pie pisang di YA dan JB

\begin{tabular}{lccccccrr}
\hline \multicolumn{1}{c}{ Atribut } & $\begin{array}{c}\text { Tingkat } \\
\text { kepentingan }\end{array}$ & $W F$ & $\begin{array}{c}\text { Tingkat } \\
\text { kinerja }\end{array}$ & $W S$ & $\begin{array}{c}\text { Tingkat } \\
\text { kepentingan }\end{array}$ & $W F$ & $\begin{array}{l}\text { Tingkat } \\
\text { kinerja }\end{array}$ & JB \\
\hline Rasa & \multicolumn{2}{c}{ YA } \\
Harga & 4,42 & 0,10 & 4,35 & 0,42 & 4,42 & 0,10 & 4,34 & 0,42 \\
Ukuran & 4,30 & 0,09 & 4,24 & 0,40 & 4,30 & 0,09 & 4,19 & 0,39 \\
Variasi Produk & 3,53 & 0,08 & 3,47 & 0,27 & 3,53 & 0,08 & 3,47 & 0,27 \\
Higenitas & 3,68 & 0,08 & 3,97 & 0,32 & 3,68 & 0,08 & 3,63 & 0,29 \\
Tanggal Kadaluarsa & 4,05 & 0,09 & 4,12 & 0,36 & 4,05 & 0,09 & 4,13 & 0,36 \\
Kemasan & 3,95 & 0,09 & 4,00 & 0,34 & 3,95 & 0,09 & 3,69 & 0,32 \\
Tekstur & 3,61 & 0,08 & 3,79 & 0,30 & 3,61 & 0,08 & 3,56 & 0,28 \\
Lokasi & 3,65 & 0,08 & 4,00 & 0,32 & 3,65 & 0,08 & 3,59 & 0,29 \\
Area Parkir & 3,71 & 0,08 & 3,82 & 0,31 & 3,71 & 0,08 & 3,97 & 0,32 \\
Kenyamanan & 3,52 & 0,08 & 3,50 & 0,27 & 3,52 & 0,08 & 3,94 & 0,30 \\
Kebersihan & 3,67 & 0,08 & 3,82 & 0,30 & 3,67 & 0,08 & 3,97 & 0,32 \\
Total Skor & 3,88 & 0,08 & 3,97 & 0,34 & 3,88 & 0,08 & 4,06 & 0,34 \\
CSI (\%) & 45,97 & 1,00 & 47,06 & 3,94 & 45,97 & 1,00 & 46,53 & 3,89 \\
\hline
\end{tabular}

kemasan pie pisang di JB tidak terdapat tanggal kadaluarsa.

\section{Kepuasan Konsumen}

Metode CSI merupakan metode pengukuran kepuasan konsumen yang sering dipakai untuk melihat atau mengukur kepuasan konsumen. Metode ini mengukur kepuasan konsumen secara keseluruhan (Index satisfaction) dari tingkat kepentingan (importance) dan tingkat kinerja (performance) (Supranto 2006). Berdasarkan pada Tabel 4, nilai Weighted Score Total yang ada pada agroindustri sebesar 3,94 di YA dan 3,89 di JB. Nilai Customer Satisfaction Index (CSI) pada produk pie pisang YA yaitu sebesar $78,76 \%$ dan $77,86 \%$ di JB. Berdasarkan hasil perhitungan Customer Satisfaction Index (CSI), konsumen pie pisang di YA dan JB menunjukkan tingkat kepuasan terhadap atribut yang dimiliki agroindustri masuk dalam kriteria puas $60,00 \%$ $80,00 \%$.

Pada perhitungan tingkat kepuasan pie pisang di YA dan JB, konsumen memberikan nilai kepuasan tertinggi pada atribut rasa, karena rasa yang enak pada pie pisang akan menjadi daya tarik konsumen ketika ingin membeli. Konsumen kedua tempat ini memberikan penilaian yang positif terhadap atribut-atribut yang dimiliki ke dua agroindustri. Sikap positif yang diberikan konsumen terlihat bahwa konsumen merasa puas terhadap kinerja yang diberikan ke dua agroindustri ini.
Hasil penelitian ini tidak jauh berbeda dengan penelitian yang dilakukan Pratama, Indriani, dan Endaryanto (2017) yang menyatakan bahwa konsumen puas setelah mengkonsumsi pecel lele dengan persentase sebesar $71,52 \%$ di Rumah Makan Ibu Safe'i dan 70,50\% di MP Asli Hang Dihi. Konsumen merasa puas dengan rasa makanan yang diberikan oleh kedua rumah makan.

\section{Importance Performance Analysis}

Peningkatan kepuasan dapat dilakukan dengan meningkatkan tingkat kepentingan dan tingkat kinerja. Grafik diagram kartesius dapat dilihat pada Gambar 1 dan 2.

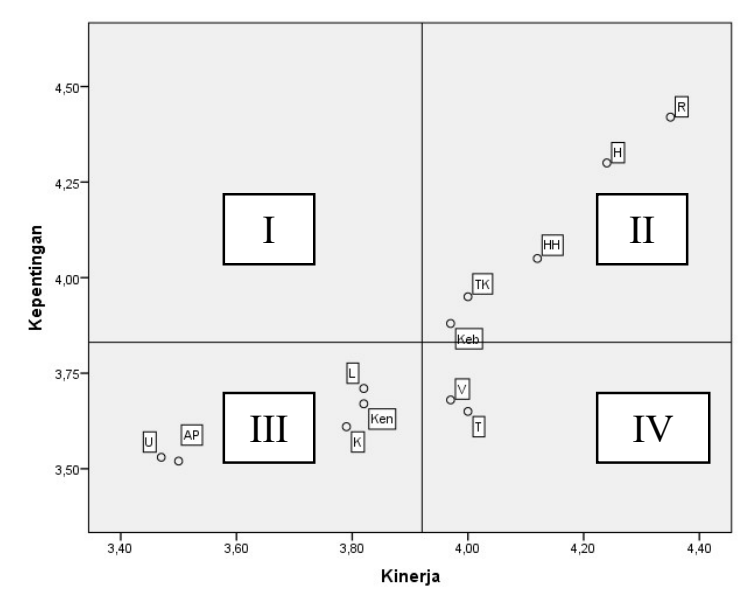

Gambar 1. Diagram Katesius YA 


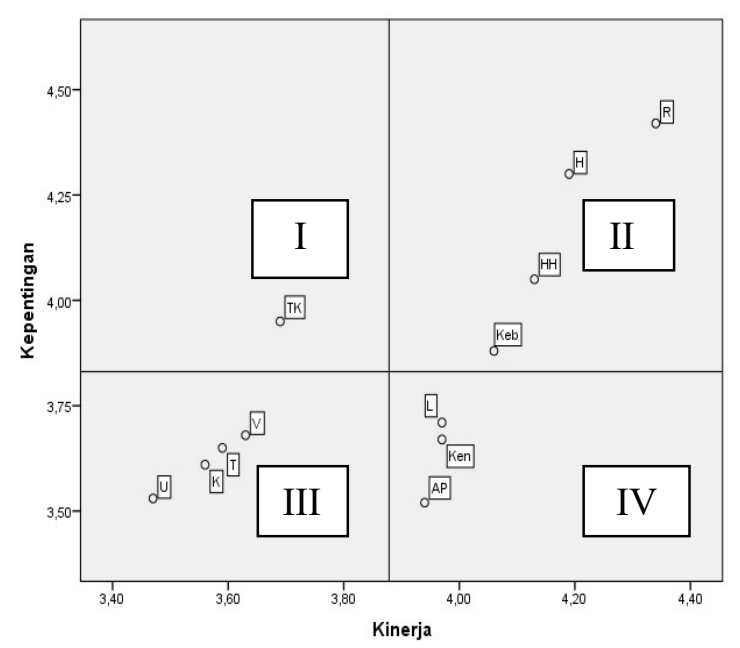

Gambar 2. Diagram Kartesius JB

Keterangan:

$\begin{aligned} \mathrm{R} & =\text { Rasa } & \mathrm{K} & =\text { Kemasan } \\ \mathrm{H} & =\text { Harga } & \mathrm{T} & =\text { Tekstur } \\ \mathrm{U} & =\text { Ukuran } & \mathrm{Ap} & =\text { Area parkir } \\ \mathrm{VP} & =\text { Variasi produk } & \mathrm{Ken} & =\text { Kenyamanan } \\ \mathrm{HH} & =\text { Higienitas } & \mathrm{Keb} & =\text { Kebersihan } \\ \mathrm{TK} & =\text { Tanggal } & \mathrm{L} & =\text { Lokasi } \\ & \text { kadaluarsa } & & \end{aligned}$

Berdasarkan perhitungan dapat digambarkan diagram kartesius Importance Performance Analysis. Atribut yang berada pada kuadran I (prioritas utama) adalah atribut tanggal kadaluarsa di JB namun, pada Agroindustri YA tidak terdapat atribut yang masuk ke dalam kuadran I. Atribut yang ada pada kuadran II (pertahankan prestasi) terdapat beberapa atribut yang sama seperti rasa, harga, kebersihan dan higenitas namun terdapat atribut tanggal kadaluarsa pada Agroindustri YA.

Kuadran III (prioritas rendah) pada Agroindustri YA adalah atribut ukuran, lokasi, kemasan, kenyamanan, dan area parkir, sedangkan pada Agroindustri JB atribut yang masuk ke dalam kuadran III adalah atribut variasi produk, ukuran, kemasan, dan tekstur. Sementara atribut yang ada pada kuadran IV (berlebihan) pada Agroindustri YA adalah atribut variasi produk dan tekstur, sedangkan pada JB yaitu atribut lokasi, kenyamanan dan area parkir.

\section{KESIMPULAN}

Konsumen pie pisang di YA dan JB didominasi oleh perempuan dengan usia 18-30 tahun. Proses pengambilan keputusan konsumen dalam pembelian pie pisang dilakukan melalui pengenalan kebutuhan, pencarian informasi, evaluasi alternatif, keputusan pembelian dan evaluasi pasca pembelian. Hasil analisis sikap pie pisang di YA dan JB menunjukan atribut rasa mendapatkan skor sikap (Ao) tertinggi, sementara atribut yang memiliki nilai rendah di YA adalah atribut area parkir dan atribut ukuran produk di JB. Tingkat kepuasan konsumen berdasarkan analisis Costomer Satisfaction Index (CSI) adalah sebesar $78,76 \%$ di YA dan $77,86 \%$ di JB yang artinya konsumen merasa puas.

Berdasarkan Importance Performance Analysis (IPA) atribut pada kuadran I (prioritas utama) adalah atribut tanggal kadaluarsa di JB, namun pada agroindustri YA tidak terdapat atribut yang masuk ke dalam kuadran I. Selanjutnya, atribut yang ada pada kuadran II (pertahankan prestasi) adalah atribut rasa, harga, kebersihan dan higenitas, namun terdapat atribut tanggal kadaluarsa pada YA. Atribut pada kuadran III (prioritas rendah) adalah atribut ukuran, lokasi, kemasan, kenyamanan, dan area parkir di YA, sedangkan pada Agroindustri JB adalah atribut variasi produk, ukuran, kemasan, dan tekstur. Atribut yang ada pada kuadran IV (berlebihan) adalah atribut variasi produk dan tekstur di YA dan pada JB yaitu atribut lokasi, kenyamanan dan area parkir.

\section{DAFTAR PUSTAKA}

Anggiasari NM, Indriani Y, dan Endaryanto T. 2016. Sikap dan pengambilan keputusan pembelian sayuran organik oleh konsumen di Kota Bandar Lampung. JIIA, 4 (4) : 391397. http://jurnal.fp.unila.ac.id/index.php/ JIA/article/view/1521. [4 Februari 2019].

Direktorat Jendral Hortikultura. 2015. Statistik Produksi Hortikultura Tahun 2014. Jakarta.

Epriani M, Indriani Y, dan Endaryanto T. 2017. Sikap konsumen dan strategi pemasaran dua merek kopi bubuk di Kota Bandar Lampung. JIIA, 5 (4) : 414 - 421. http://jurnal.fp.unila. ac.id/index.php/JIA/article/view/1751/1554. [4 Februari 2019 ].

Ghozali I. 2005. Aplikasi Analisis Multivariate Dengan Program SPSS. Badan Penerbit Universitas Diponegoro. Semarang.

2009. Aplikasi Analisis Multivariate Dengan Program SPSS. Badan Penerbit Universitas Diponegoro. Semarang.

Isaac S, dan Michael W. 1981. Handbook In Research and Evaluation. Edits Publishers. California.

Kuswara. 2013. Analisis Perilaku dan Kepuasan dalam Proses Keputusan Pembelian Lapis 
Bogor Sangkuriang. Skripsi. Institut Pertanian Bogor. Bogor. http://repository. ipb.ac.id/jspui/bitstream/123456789/67664/1 /H13eku.pdf. [20 September 2018].

Mantra IB. 2003. Demografi Umum Edisi Ke dua. Pustaka Belajar. Yogyakarta.

Mowen JT dan Minor M. 2002. Perilaku Konsumen, Jilid 1 Edisi Kelima. Erlangga. Jakarta.

Nissa. 2013. Analisis Proses Keputusan Pembelian dan Kepuasan Konsumen Produk Teh. Skripsi. Institut Pertanian Bogor. Bogor. http://repository.Ipb.ac.id/jspui/bitstream/ 123456789/63914/1/H13fkn.pdf. September 2018].

Pratama DY, Indriani Y, dan Endaryanto T. 2017. Sikap dan kepuasan konsumen terhadap konsumsi makanan pecel lele di Kota Bandar Lampung. JIIA, 5 (2): 200-205.
http://jurnal.fp.unila.ac.id/index.php/JIA/ article/view/1659. [4 Februari 2019]. Sugiyono. 2010. Metode Penelitian Kuantitatif Kualitatif dan $R \& D$. Alfabeta: Bandung. Satuhu. 2000. Pisang : Pisang Budidaya, Pengolahan, dan Prospek Pasar. Penebar Swadaya. Jakarta.

Supranto J. 2006. Pengukuran Tingkat Kepuasan Pelanggan untuk Meningkatkan Pangsa Pasar. Rineka Cipta. Jakarta.

Suryani T. 2012. Perilaku Konsumen ; Implikasi Terhadap Strategi Pemasaran. Graha Ilmu: Yogyakarta.

Syarifatunisa. 2011. Strategi peningkatan kepuasan pelanggan Toko Roti Unyil Venus Bogor. Skripsi. Institut Pertanian Bogor. Bogor. Diakses pada 20 September 2018 pukul 13.00 . 